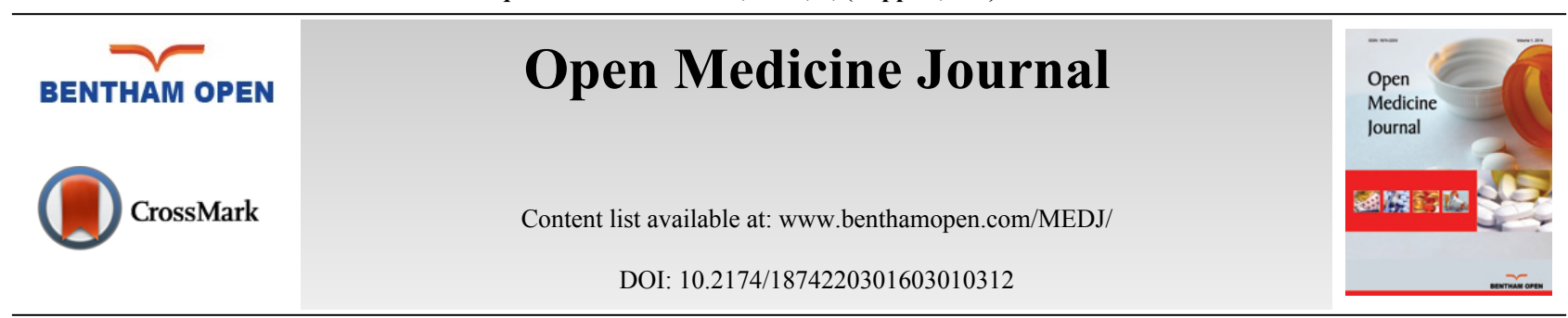

REVIEW ARTICLE

\title{
Teaching Anatomy; Dissecting its Delivery in Medical Education
}

\author{
DJ Jordan ${ }^{1, *}$, M Griffin ${ }^{2}$, B Phillips ${ }^{3}$, S Hindocha ${ }^{1}$ and A Elgawad ${ }^{1}$ \\ ${ }^{I}$ Department of Plastic Surgery, Whiston Hospital, L35 5DR, Liverpool, UK \\ ${ }^{2}$ St. Georges Hospital, Tooting, London, UK, SW17 0QT, UK \\ ${ }^{3}$ University of Liverpool Medical School, Liverpool, UK
}

Received: July 04, 2015

Revised: September 17, 2016

Accepted: September 17, 2016

\begin{abstract}
Anatomy has long been a topic of interest amongst both those in medicine and those not. The understanding of biology, in terms of the function and structure of the organs and other structures of the body, has dramatically changed over time, and has been closely related to both scientific improvement and religious feeling.

There is no doubt that gross anatomy is one of the preclinical cornerstones of medical education, but the way in which it has been taught has changed over the years. As early as the $16^{\text {th }}$ century, Vesalius stated that anatomy could only be taught by dissection, however, alternative options for cadaveric study are certainly more available now than when this statement was made.

Current teaching methods incorporate the tried and tested cadaveric based dissection, but has more recently been super ceded by the use of computer based imaging and the change to self-orientated or problem based learning. The shift towards the latter has led to a perceived suffering to the gain of anatomical and pathological knowledge of new doctors and surgeons.
\end{abstract}

This paper aims to describe the history of anatomy teaching and review the current evidence for and against the current methods used for its deliverance.

Keywords: Anatomy, Medical education, Surgical practice, Teaching.

\section{ANATOMY; WHY BOTHER?}

Human anatomy refers specifically to the consideration of the various structures that make up the human body. This can be separated into systematic or regional anatomy sections; the first describing certain characteristics for instance osteology; focusing on the human skeleton, and angiology; looking at the vascular system. The latter description, regional anatomy, takes into account all of the individual systems and notes how they interact and function together in a certain region e.g. the lower limb, or the thorax. In addition to this anatomy encompasses both adult and embryological anatomy, as well as applied and clinical anatomy; the direct application of the pathological conditions which may occur, and a practical application of anatomy [1].

There is no doubt that gross anatomy is one of the preclinical cornerstones of medical education [2,3]. Every doctor must grasp the concepts of anatomy to aid in appropriate diagnosis and management of their patient, as well as communication with peers and patients, and it comes as no surprise that anatomy and surgical practice must be interrelated.

Doctors need to have a firm understanding of anatomy and this should be based on a theoretical knowledge, a practical 3D application of this knowledge, as well as an appropriate bedside or clinical application on the patient [4].

Current perception is that anatomy knowledge in inadequate, with a belief amongst senior surgical program directors in the UK feeling that knowledge of anatomy was lacking, or in need of a refresher course, in a total of $91 \%$ of new doctors. This was further supplemented with $52 \%$ feeling that anatomical knowledge was significantly less in new

\footnotetext{
* Address correspondence to this author at the Department of Plastic Surgery, Whiston Hospital, L35 5DR, Liverpool, UK; Tel: + 44(0)1244366265; Fax: +44(0)1244366265; E-mail: jord_is@hotmail.com
} 
graduates than those graduating 10 years ago [3].

Likewise, there has been an increase in anatomical competence related claims with both avoidable death and morbidity seen as a consequence [5 - 7].

\section{ANATOMY; A SOURCE OF FASCINATION THROUGH THE AGES}

The desire to understand the human body dates back to written records, with the Egyptians noted first to show interest in the body's make up. The Edwin Smith Surgical Papyrus dates back to 1500BC and describes vessels emanating from drawn organs, symbolizing the heart, liver, spleen, kidney and bladder, which carry air, mucus, the 'breath of life' and the 'breath of death.' Other Egyptian records show an understanding that the heart is the centre of the blood supply, and vessels to the major members of the body are required [8].

Anatomy methods and nomenclature can be dated more specifically to the time of the Greek physicians [9]. Animal dissection was used predominately, but around 480BC the optic nerve and Eustachian tubes were identified, with Empedocles stating the human heart was the primary organ involved in both the vascular sense and for distributing the 'breath' around the body.

Comparative anatomy, mainly due to animal dissections, was described by Aristotle in the $4^{\text {th }}$ century BC, with Praxagoras credited for defining arteries and veins.

Ptolemy I allowed the first studies of dead bodies in $300 \mathrm{BC}$, with the Greek physicians Herophilos and Erasistratus noted for their dissections on dead criminals in Alexandria, Egypt [10,11]. The former, often called the founder of anatomy, was later accused of performing his dissections on live criminals [12].

Hippocrates, the 'Father of Medicine,' continued anatomical studies in $460 \mathrm{BC}$.

The $2^{\text {nd }}$ century saw Galen write his two works on anatomy; On anatomical procedure and On the uses of the parts of the body of man. These would become the main sources of anatomical teaching until the $16^{\text {th }}$ century and were based on his findings through animal dissection, his work as a gladiatorial physician and a compilation of the works of previous writers $[9,10]$.

His writings include the first description of seven pairs of cranial nerves, and the passage of blood rather than the precluding opinion of air and mucus in the blood vessels.

The period between the $8^{\text {th }}$ and $15^{\text {th }}$ centuries was of poor input to anatomy. This time was of profound Christian belief, and scientific enquiry was not promoted. For this time, Galen's commentary became the accepted.

The $13^{\text {th }}$ century saw several anatomists allowed to dissect human cadavers with Mondino de Luzzi, Alessandro Achillini and Antonio Benivieni amongst those noted for their work [13 - 15].

Leonardo da Vinci, dissected over 30 human specimens during his life. These are depicted in a wide range of his drawings, found in the anatomical Manuscript B, dating back to 1489 .

The $16^{\text {th }}$ century saw Andreas Vesalius challenge the teachings of Galen. His widespread travels in search of condemned men, and dissection of them after death, allowed a more detailed study of human anatomy, allowing a challenge to be made between these new findings and those previously 'known' after comparative dissection in animals by Galen. It was at this time anatomy was noted to be significant to the discipline of medicine, with Vesalius stating that anatomy could only be taught by dissection. In 1543, Vesalius would publish his great work De humani corporis fabrica, or 'the structure of the human body,' and from this human anatomical studies would stride forward [16].

Vesalius pupil, MR Columbus would go onto describe accurately the anatomy of bones, the cavities of the heart, as well as comment on the larynx and brain.

The hepatic vessels, lymphatic system and left to right ventricle flow of the heart were soon described, with Italy becoming a centre for anatomy teaching and vivisection.

These teachings would take place from 1490 in anatomical theatres, such as in Padau [17], where hired hands would dissect a cadaver whilst professors educated those sat in the amphitheaters on the parts being dissected. This way of teaching, not only for those in medicine, would continue until the $19^{\text {th }}$ century where cadaveric teaching would move to the classroom.

The importance of anatomy was noted by Giovanni Battisti Morgagni, consequently described as the father of 
modern autopsy, believing it to be key for diagnosis and treatment [18].

With an increase in interest into anatomy, growing numbers of medical trainees and a limit to the number of accessible cadavers, the $17^{\text {th }}$ and $18^{\text {th }}$ century saw the peak of grave-robbing, or body snatching, as well as people being murdered for the sale of their body to anatomy schools $[19,20]$.

The Anatomy Act was passed in Britain in 1832 which allowed both a legitimate and adequate source of corpses by allowing legal dissection on executed murderers, likewise dissection was only permitted to be carried out by physicians or barber surgeons [21].

The $19^{\text {th }}$ century saw an increase in anatomical research. This involved both developmental biology and histology studies, both allowed by the improvement in microscopy and research skills.

The continued development in technology has brought us to the modern day, where radiology has revolutionized the study of living tissues. In particular MRI and CT machines have allowed unprecedented details of both living and dead tissue, and interest has moved to function and evolution of anatomy as the macroscopic aspects of human anatomy have been largely noted.

Alongside a greater ability to view the human body, the preservation of its anatomical specimens has improved. Latex injection and plastination has allowed detailed alternatives to a deceased body, as has the vast improvement in photography and imaging $[22,23]$.

Clinical, or living, anatomy, with the use of living models, has also increased as our understanding of the relationship between the outside and inside of the body has improved, with many schools for instance advocating the use of ultrasound teaching, for instance in anatomy of the neck [24, 25] and heart [26].

\section{ANATOMY; TRAINING THE MODERN DOCTOR}

A doctor's anatomical knowledge begins in medical school and ultimately progresses throughout their career [27]. Following the General Medical Council's (GMC) recommendations (1993) in 'Tomorrows Doctor's', which stated that [28]:

- Too much emphasis in medical school was based on factual content and too little on clinically relevant content.

- An increased proportion of learning should be student-centered and self-directed.

- Medical schools must implement a curriculum that provides the skills, knowledge and attitudes required for students' professional development.

Many medical schools were encouraged to restructure their medical curriculums, with many opting for a Problem Based Learning (PBL) course as it was felt that contextual learning helped retain knowledge [29]. The GMC offers no guidance on what is considered the minimum level of knowledge requirement in each medical subject [30]. Rather, medical schools have freedom to interpret and form their curricula [30]. In implementing these changes to the course structure and an ever increasing magnitude of skills and knowledge required in medicine there has been a general reduction in anatomy contact time in many medical schools [31]. Statistics show a reduction of as much as $60 \%$ in contact time since 1980 in some medical schools [32].

A generalised decline in dissection based anatomy teaching has been observed since the implementation of the new curricula, with a move towards new teaching methods to, in theory, save time with an ever increasing medical student population and improve retention of knowledge [33].

\section{ANATOMY; THE TEACHING TOOLS}

Currently, anatomical teaching methods can crudely be split into three main categories [34]:

- Cadaveric.

- Computer assisted learning (CAL).

- Problem based learning (PBL) teaching sessions or traditional lecture based teaching.

Also included are two subsequent teaching methods that are common to all three categories: 
1. Clinical based teaching.

2. Teaching using anatomical models and textbooks.

\section{CADAVERIC BASED TEACHING}

Cadaveric dissection dates back as early as anatomy itself. Todays specimens are generally donated to medical research, and still presents the age old difficulty of numbers able to be found. This has not been aided by Human Tissue Act of 2004 as well as viral outbreaks including Bovine Spongiform Encephalitis limiting the amount of tissue handling and resources [35 - 38].

This has been circumvented by some institutions with the use of prosections, where a demonstrator dissects and educates to a group of students.

Cadaveric dissection, in general, involves a team of students being assigned to a donor and working to dissect out an anatomical region as described and supported in related lectured teaching. In addition to the anatomy teaching, it has been suggested that it helps to develop teamwork, improve practical skills and incorporates a feeling of understanding the history of medicine [39].

This study also comments on the ethical and religious concerns regarding this teaching method, as well as the emotional confrontation of the cadaveric dissection.

Cadaveric dissection is still felt, amongst both anatomists and students, to be the most 'fit for purpose' teaching method to meet learning outcomes, although it may not meet them all [40, 41].

Plastinated prosections is a middle ground option, where surveys have seen as high as $96 \%$ satisfaction with these models due to highly detailed relevant anatomy showing the anatomical relationships. However, this is compromised by a reduction in tactile and emotional experience [42], as well as a belief of inadequate training compared to peers [43].

Cadaveric surgery is a variant on the original cadaveric dissection method and is one new possible option being explored for the teaching of clinical anatomy.

This method has already been implemented in postgraduate surgical technique training [44] and is now being considered as a method for teaching clinically relevant anatomy and surgical techniques in tandem [45]. Examples of its use include teaching intra-abdominal pathology with the use of laparoscopy in cadaveric specimens [46].

The advantage of cadaveric surgery is that hands-on visualization allows the student/trainee to immediately grasp the functions and anatomical relations of each structure [44]. It has many similarities with the original dissection based anatomy teaching method, however by providing students with a surgical task, it requires concentration on a specific anatomical location in depth whilst maintaining interest and exposure to surgical skills [45]. The one advantage of cadaveric surgery over simple dissection based learning is it provides students with a lasting memory of the procedure, therefore helping to prompt the underlying anatomy knowledge learnt at this time.

Due to the high similarities between cadaveric surgery and simple dissection based teaching it shares many of the same disadvantages. A number of students can suffer from anxiety when entering a cadaveric dissection room and can avoid participating in dissection due to religious, ethical or other reasons [47, 48].

The reduction in cadaveric donations has also been a factor which has added to the gradual decline in dissection based anatomy teaching [37].

A newer technique of embalming bodies, the Thiel method, is a developing field. Described in Austria first, it may offer an alternative to current cadaveric issues regarding storage and cost $[49,50]$.

The problems regarding the future of cadaveric dissections mainly lies with reduced dissection time, leading to poor efficiency regarding the cost of maintain a dissection room, and a reduction in suitably trained anatomists meaning a poorer teaching environment [51].

\section{COMPUTER ASSISTED LEARNING (CAL)}

With increasing costs and difficulties in acquiring cadavers for anatomical dissection, anatomy departments have look to new innovative methods to deliver their teaching [52]. This lead to integration of CAL.

In recent times CAL has increasingly become a vital teaching method now adopted by many medical schools and surgical training programs. The use of podcasts, dissection videos, online anatomy tutorials and virtual 3D anatomical 
models with the ability to rotate and zoom has increased among students.

Support for CAL in anatomy teaching has been questionable in the past, with many believing the detail of such content was far inferior to dissection-based teaching. In recent year the technology used in CAL and the detail has improved greatly. CAL has several advantages over dissection-based teaching in that the student can revisit material and access teaching material when needed [53]. CAL is especially advantageous when highly complex anatomical areas or difficult to access areas on a cadaver such as the neck are being studied [34, 53].

Results from the literature are inconsistent regarding the effectiveness in CAL for anatomy teaching. One study showed that student satisfaction and faith in CAL was far less than traditional dissection based methods [54]. In contrast a second study found that $62 \%$ of students felt that CAL was of great importance in anatomy teaching and $20 \%$ of these had a strong preference for CAL over dissection [52]. There seems to be a trend where traditionalist anatomists advocate dissection, with students on the other hand feeling that a dissection based approach is not always the most useful method of learning $[27,55]$.

A major problem with CAL, like any computer-based system success is usually determined by the standard of software used, the accessibility of software e.g. accessible from home and to what standard it has been implemented efficiently and effectively into the teaching environment. There can also be issues regarding their generic content, and whether one institutes CAL is suitable for other units [56].

However, as CAL is now being integrated into all aspects of medicine, with virtual laparoscopic simulators being at the forefront of surgical training it seems likely that as technology advances there will be an increase in CAL throughout medicine, including anatomy teaching [57].

\section{PROBLEM BASED LEARNING (PBL) \& TRADITIONAL LECTURE BASED CURRICULUM}

Since the advent of medical curricular change in the UK, predominantly since the publication of 'Tomorrows Doctors' in 1993 by the GMC [28], a divide among medical schools in teaching formats has arisen:

- Traditional medical curriculum (TMC).

- Problem based learning (PBL).

A TMC usually consists of two years preclinical and the succeeding years clinical, with emphasis on lectures [58]. In comparison to TMC, PBL courses have clinical teaching taught alongside basic sciences [59]. Students are placed in small groups or tutorials allowing them to independently set the learning objectives and then, subsequently share this new knowledge with their fellow group members in the next group tutorial meeting. This places a large emphasis on self-learning, with the absence of significant lecture teaching. This method of learning anatomy has been highly criticised, with critics skeptical regarding the effectiveness of self directed anatomy learning and believing students receive little support and guidance as what to learn.

Since implementation, these contrasting teaching methods have become the centre of a fierce debate regarding the effectiveness of anatomy teaching in the more modern PBL approach [60, 61].

Some doctors believe that students who study at medical schools offering PBL have deficiencies in their knowledge of basic sciences, especially anatomy, although this may be based on overall levels of knowledge as opposed to the teaching method used [62].

There is an abundance of papers comparing PBL vs. TMC but surprisingly very few concerning the basic sciences, especially anatomical knowledge. Conclusions from papers researching this topic have either been inconclusive or inconsistent [63]. This inconsistency is partly due to there not being a definitive definition for PBL since its creation over 40 years ago [64]. Meaning that the true format of medical schools offering PBL courses can vary tremendously.

Another comment on PBL notes that student feel a need to find a problem's diagnosis or solution without adequate understanding of the causes or underlying mechanisms [65], an area which would include anatomical knowledge.

\section{ANATOMY; THE FUTURE}

Anatomy teaching has evolved enormously in the past two decades. As stated earlier, with an ever-expanding medical curriculum it does seem that the basic sciences have been neglected more than would be liked [31, 32]. However, anatomy is still vital for medical practice and it seems unlikely that more anatomy based teaching time will 
be removed from future curriculums. Medical schools and surgical trainee programs will have to increase the effectiveness of the current limited allocated time.

With the ever-increasing cost of cadaveric dissection and the constant development in technology, it seems that as anatomy curriculums evolve further a move towards CAL will be seen, in line with modern times.

This has been noted, with the first medical school in the UK designing its anatomy teaching without the use of cadavers [66]. Although it is also noted that previous institutes that have moved away from cadaveric dissection have often returned to this technique at a later date [67].

Time spent learning anatomy, including revision of topics and in clinical context may play a role of more importance than the teaching curriculum method used [68].

A combination approach to teaching anatomy appears to be the sensible course and has been trialed [69 - 71] although there is no defined way of analyzing which method, or combination of methods, is best.

Cadaveric dissection still has an important role to play in anatomy teaching. This is recognized by multiple papers, including those that integrate the multi-modal teaching approach with students stating the dissection room helps ingrain the previously learnt knowledge as well as improve their understanding particularly in a 3D perspective [27].

This perception of dissection has not yet been replaced by the introduction of problem based learning and interactive multimedia resources, although aspects of these newer methods are considered useful [40, 41, 72].

\section{CONCLUSION}

There are numerous methods of anatomy teaching currently available to the undergraduate and postgraduate trainee. The fierce debate will continue on regarding the effectiveness of each among traditionalists and liberalists.

Dissection has been the cornerstone of anatomy for centuries and we are now seeing a gradual move away from the tried and tested art.

Medical schools have limited their allocated teaching time for anatomy and have subsequently had to invent new innovative ways to teach the subject in a manner that saves time. However the quality of teaching provided and standard of anatomical knowledge of new graduates is often said to be lower than that of past medical graduates, leading to low confidence in new methods [73].

No doubt medical students and surgical trainees will chose a teaching method when selecting at which institution to study. Therefore medical schools and surgical trainee programs may have to adapt their courses in the future in order to appeal to the majority of students. However what is vital for future patient care is that anatomy teaching time must not be reduced further and if possible increased to improve the basic understanding of anatomy that underpins clinical practice.

In general, there is a need for research and external audit into the methods of teaching, specifically anatomy, with no common national core curriculum or agreement currently seen [74 - 76], although this is noted as an area requiring assessment [77].

It has been noted that a reduction in undergraduate teaching and anatomical knowledge is of concern to both the under and post graduate doctor, and this in combination with a change in basic surgical training has set up a system allowing the potentially anatomically naive doctor to become a surgeon $[51,74,75,78]$.

It should be noted that the modernized medical career may place detailed anatomical knowledge unnecessary for the majority of modern doctors, and other 'core areas' are deemed as important for the formation of a the generic doctor. For the surgeon, however, this is not appropriate and there needs to be a shift towards opportunity and exposure to learn detailed anatomy, but possibly at later stage of their training.

Robert Liston phrases this well with his quote:

\section{The foundation of the study of the art of operating must be laid in the dissecting room.}

Saying this there is something intrinsic to the majority of medical students regarding a fascination with human anatomy, and this is mirrored both in non medical staff and the general public. With this new innovations and ways of teaching anatomy will be developed and should be incorporated into the curricula of our trainees, but not at the complete abandonment of methods that have already stood the test of time. 


\section{CONFLICT OF INTEREST}

The authors confirm that this article content has no conflict of interest.

\section{ACKNOWLEDGEMENTS}

Declared none.

\section{REFERENCES}

[1] Gray Henry. Anatomy of the Human Body Philadelphia, Lea \& Febiger 1918. [http://dx.doi.org/10.5962/bhl.title.20311]

[2] Pabst R, Rothkötter H-J. Retrospective evaluation of undergraduate medical education by doctors at the end of their residency time in hospitals: consequences for the anatomical curriculum. Anat Rec 1997; 249(4): 431-4. [http://dx.doi.org/10.1002/(SICI)1097-0185(199712)249:4<431::AID-AR1>3.0.CO;2-U] [PMID: 9415449]

[3] Cottam WW. Adequacy of medical school gross anatomy education as perceived by certain postgraduate residency programs and anatomy course directors. Clin Anat 1999; 12(1): 55-65.

[http://dx.doi.org/10.1002/(SICI)1098-2353(1999)12:1<55::AID-CA8>3.0.CO;2-O] [PMID: 9890730]

[4] Schoeman S, Chandratilake M. The anatomy competence score: a new marker for anatomical ability. Anat Sci Educ 2012; 5(1): 33-40. [http://dx.doi.org/10.1002/ase.263] [PMID: 22127894]

[5] Green NA. Anatomy training for surgeonsa personal viewpoint. J R Coll Surg Edinb 1998; 43(1): 69-70. [PMID: 9560520]

[6] Cahill DR, Leonard RJ, Marks SC Jr. Standards in health care and medical education. Clin Anat 2000; $13(2): 150$. [http://dx.doi.org/10.1002/(SICI)1098-2353(2000)13:2<150::AID-CA12>3.0.CO;2-V] [PMID: 10679860]

[7] Ellis H. Medico-legal litigation and its links with surgical anatomy. Surgery 2002; 20(8): i-ii.

[8] Allen James P. The art of medicine in ancient egypt. New York: The Metropolitan Museum of Art 2005; p. 70.

[9] Singer C. A short history of anatomy \& physiology from greeks to harvey. New York: Dover Publications Inc. 1957; pp. 5-10.

[10] Siddiquey AK, Husain SM, Laila SZ. History of Anatomy. Bangladesh J Anat 2009; 7(1): 1-3. [http://dx.doi.org/10.3329/bja.v7i1.3008]

[11] Staden HV. Herophilus the art of medicine in early alexandria. Cambridge, Mass, USA: Cambridge University Press 2004.

[12] Roach M. Stiff: the curious lives of human cadavers. New York: W.W. Norton 2003; p. 41.

[13] Zimmerman LM. Veith, Ilza great ideas in the history of surgery. Crombie: Norman Publishing 1993.

[14] Cameron A. The History of Science From Augustine to Galileo. Courier Dover Publications 1959.

[15] Benivieni A, Polybus, Guinterius Joannes. De abditis nonnullis ac mirandis morborum \& sanationum causis apud Andream Cratandrum. 1529.

[16] Vesalius A. De Humani Corporis Fabrica. Basel, Switzerland: J. Oporinus 1543.

[17] Klestinec C. A history of anatomy theaters in sixteenth-century Padua. J Hist Med Allied Sci 2004; 59(3): $375-412$. [http://dx.doi.org/10.1093/jhmas/jrh089] [PMID: 15270335]

[18] Morgagni GB. De Sedibus et Causis Morborum[On the Sites and Causes of Diseases] 1761.

[19] Rosner L. The anatomy murders being the and spectacular history of edinburgh's notorious burke and hare and of the man of science who abetted them in the commission of their most heinous crimes. University of Pennsylvania Press 2010.

[20] Moore W. The knife man: blood, body-snatching and the birth of modern surgery. In: Bantam. 2006; pp. 87-95.

[21] The Anatomy Act 1832 (2 \& 3 Will. IV c.75) Great Britain.. (Act of Parliament).

[22] von Hagens G, Tiedemann K, Kriz W. The current potential of plastination. Anat Embryol (Berl) 1987; $175(4)$ : $411-21$. [http://dx.doi.org/10.1007/BF00309677] [PMID: 3555158]

[23] Dhingra R, Taranikanti V, Kumar R. Plastination: teaching aids in anatomy revisited. Natl Med J India 2006; $19(3)$ : 171. [PMID: 16838416]

[24] Jurjus RA, Dimorier K, Brown K, et al. Can anatomists teach living anatomy using ultrasound as a teaching tool?. Anat Sci Educ 2014; 7(5): 340-9.

[25] Brown B, Adhikari S, Marx J, Lander L, Todd GL. Introduction of ultrasound into gross anatomy curriculum: perceptions of medical students. J Emerg Med 2012; 43(6): 1098-102. [http://dx.doi.org/10.1016/j.jemermed.2012.01.041] [PMID: 22459597]

[26] Griksaitis MJ, Sawdon MA, Finn GM. Ultrasound and cadaveric prosections as methods for teaching cardiac anatomy: a comparative study. Anat Sci Educ 2012; 5(1): 20-6.

[http://dx.doi.org/10.1002/ase.259] [PMID: 22069248] 
[27] Azer SA, Eizenberg N. Do we need dissection in an integrated problem-based learning medical course? Perceptions of first- and second-year students. Surg Radiol Anat 2007; 29(2): 173-80. [http://dx.doi.org/10.1007/s00276-007-0180-x] [PMID: 17318286]

[28] Council GM. Tomorrows Doctors. GMC 2009

[29] Regehr G, Norman GR. Issues in cognitive psychology: implications for professional education. Acad Med 1996; 71(9): 988-1001. [http://dx.doi.org/10.1097/00001888-199609000-00015] [PMID: 9125988]

[30] Turney BW. Anatomy in a modern medical curriculum. Ann R Coll Surg Engl 2007; 89(2): 104-7. [http://dx.doi.org/10.1308/003588407X168244] [PMID: 17346399]

[31] Gupta Y, Morgan M, Singh A, Ellis H. Junior doctors knowledge of applied clinical anatomy. Clin Anat 2008; 21(4): 334-8. [http://dx.doi.org/10.1002/ca.20628] [PMID: 18428998]

[32] Pryde FR, Black SM. Anatomy in Scotland: 20 years of change. Scott Med J 2005; 50(3): 96-8. [PMID: 16163991]

[33] McKeown PP, Heylings DJ, Stevenson M, McKelvey KJ, Nixon JR, McCluskey DR. The impact of curricular change on medical students knowledge of anatomy. Med Educ 2003; 37(11): 954-61. [http://dx.doi.org/10.1046/j.1365-2923.2003.01670.x] [PMID: 14629407]

[34] Bergman EM, van der Vleuten CP, Scherpbier AJ. Why dont they know enough about anatomy? A narrative review. Med Teach 2011; 33(5): 403-9. [http://dx.doi.org/10.3109/0142159X.2010.536276] [PMID: 21355704]

[35] Furness P. Consent to using human tissue. BMJ 2003; 327(7418): 759-60. [http://dx.doi.org/10.1136/bmj.327.7418.759] [PMID: 14525848]

[36] McLachlan JC. New path for teaching anatomy: living anatomy and medical imaging vs. dissection. Anat Rec B New Anat $2004 ; 281(1)$ : 4-5. [http://dx.doi.org/10.1002/ar.b.20040] [PMID: 15558778]

[37] McLachlan JC, Patten D. Anatomy teaching: ghosts of the past, present and future. Med Educ 2006; 40(3): $243-53$. [http://dx.doi.org/10.1111/j.1365-2929.2006.02401.x] [PMID: 16483327]

[38] Demiryürek D, Bayramoğlu A, Ustaçelebi S. Infective agents in fixed human cadavers: a brief review and suggested guidelines. Anat Rec 2002; 269(4): 194-7. [http://dx.doi.org/10.1002/ar.10143] [PMID: 12209557]

[39] Lempp HK. Perceptions of dissection by students in one medical school: beyond learning about anatomy. A qualitative study. Med Educ 2005; 39(3): 318-25. [http://dx.doi.org/10.1111/j.1365-2929.2005.02095.x] [PMID: 15733168]

[40] Kerby J, Shukur ZN, Shalhoub J. The relationships between learning outcomes and methods of teaching anatomy as perceived by medical students. Clin Anat 2011; 24(4): 489-97. [http://dx.doi.org/10.1002/ca.21059] [PMID: 20949485]

[41] Davis CR, Bates AS, Ellis H, Roberts AM. Human Anatomy: Let the students tell us how to teach. Anat Sci Educ 2014; 7(4): $262-72$. [PMID: 24249485]

[42] Fruhstorfer BH, Palmer J, Brydges S, Abrahams PH. The use of plastinated prosections for teaching anatomythe view of medical students on the value of this learning resource. Clin Anat 2011; 24(2): 246-52. [http://dx.doi.org/10.1002/ca.21107] [PMID: 21322047]

[43] Hasan T, Ageely H, Bani I. Effective anatomy education—a review of medical literature. Rawal Med J 2011; 36(3): 225-9.

[44] Holland JP, Waugh L, Horgan A, Paleri V, Deehan DJ, Holland JP, et al. Cadaveric hands-on training for surgical specialties: is this back to the future for surgical skills development? J Surg Educ 2011; 68(2): 110-6. [http://dx.doi.org/10.1016/j.jsurg.2010.10.002] [PMID: 21338966]

[45] Nutt J, Mehdian R, Parkin I, Dent J, Kellett C. Cadaveric surgery: a novel approach to teaching clinical anatomy. Clin Teach 2012; 9(3): $148-51$ [http://dx.doi.org/10.1111/j.1743-498X.2012.00536.x] [PMID: 22587312]

[46] Fitzpatrick CM, Kolesari GL, Brasel KJ. Teaching anatomy with surgeons' tools: use of the laparoscope in clinical anatomy. Clin Anat 2001; 14(5): 349-53

[47] Horne DJ, Tiller JW, Eizenberg N, Tashevska M, Biddle N. Reactions of first-year medical students to their initial encounter with a cadaver in the dissecting room. Acad Med 1990; 65(10): 645-6. [http://dx.doi.org/10.1097/00001888-199010000-00011] [PMID: 2261042]

[48] Naz S, Nazir G, Iram S, et al. Perceptions of cadaveric dissection in anatomy teaching. J Ayub Med Coll Abbottabad 2011; 23(3): 145-8. [PMID: 23272457]

[49] Thiel W. The preservation of the whole corpse with natural color. Ann Anat 1992; 174(3): 185-95. [http://dx.doi.org/10.1016/S0940-9602(11)80346-8] [PMID: 1503236]

[50] Eisma R, Lamb C, Soames RW. From formalin to Thiel embalming: What changes? One anatomy departments experiences. Clin Anat 2013; 
26(5): 564-71.

[http://dx.doi.org/10.1002/ca.22222] [PMID: 23408386]

[51] Sugand K, Abrahams P, Khurana A. The anatomy of anatomy: a review for its modernization. Anat Sci Educ 2010; $3(2)$ : 83-93. [PMID: 20205265]

[52] Fazal Ur R, Khan SN, Yunus SM. Students, perception of computer assisted teaching and learning of anatomy- in a scenario where cadavers are lacking. Biomedical Research 2012; 23(2): 215-8.

[53] Tam MD, Hart AR, Williams S, Heylings D, Leinster S. Is learning anatomy facilitated by computer-aided learning? A review of the literature. Med Teach 2009; 31(9): e393-6

[http://dx.doi.org/10.1080/01421590802650092] [PMID: 19811174]

[54] Chapman SJ, Hakeem AR, Marangoni G, Prasad KR, Chapman SJ, Hakeem AR, et al. Anatomy in medical education: Perceptions of undergraduate medical students. Annals of Anatomy -. Anat Anz 2013; 195(5): 409. [http://dx.doi.org/10.1016/j.aanat.2013.03.005]

[55] Patel KM, Moxham BJ, Patel KM, Moxham BJ. Attitudes of professional anatomists to curricular change. Clin Anat 2006; 19 (2): 132-41. [http://dx.doi.org/10.1002/ca.20249] [PMID: 16302246]

[56] Van Sint Jan S, Crudele M, Gashegu J, et al. Development of multimedia learning modules for teaching human anatomy: application to osteology and functional anatomy. Anat Rec B New Anat 2003; 272(1): 98-106. [http://dx.doi.org/10.1002/ar.b.10020] [PMID: 12731076]

[57] Zhang L, Grosdemouge C, Arikatla VS, et al. The added value of virtual reality technology and force feedback for surgical training simulators. Work 2012; 41(Suppl. 1): 2288-92. [PMID: 22317056]

[58] Watmough S, Cherry MG, Osullivan H, Watmough S, Cherry MG, OSullivan H. A comparison of self-perceived competencies of traditional and reformed curriculum graduates 6 years after graduation. Med Teach 2012; 34(7): 562-8. [http://dx.doi.org/10.3109/0142159X.2012.675457] [PMID: 22494079]

[59] Hinduja K, Samuel R, Mitchell S. Problem-based learning: is anatomy a casualty? Surgeon 2005; 3(2): 84-7. [http://dx.doi.org/10.1016/S1479-666X(05)80067-8] [PMID: 15861942]

[60] Dolmans D. The effectiveness of PBL: the debate continues. Some concerns about the BEME movement. Med Educ 2003; 37(12): 1129-30. [http://dx.doi.org/10.1046/j.1365-2923.2003.01724.x] [PMID: 14984122]

[61] Farrow R, Norman G. The effectiveness of PBL: the debate continues. Is meta-analysis helpful? Med Educ 2003; 37(12): 1131-2. [http://dx.doi.org/10.1046/j.1365-2923.2003.01725.x] [PMID: 14984123]

[62] Prince KJ, van Mameren H, Hylkema N, Drukker J, Scherpbier AJ, van der Vleuten CP. Does problem-based learning lead to deficiencies in basic science knowledge? An empirical case on anatomy. Med Educ 2003; 37(1): 15-21. [http://dx.doi.org/10.1046/j.1365-2923.2003.01402.x] [PMID: 12535111]

[63] Albanese MA, Mitchell S. Problem-based learning: a review of literature on its outcomes and implementation issues. Acad Med 1993; 68(1): $52-81$. [http://dx.doi.org/10.1097/00001888-199301000-00012] [PMID: 8447896]

[64] Taylor D, Miflin B. Problem-based learning: where are we now? Med Teach 2008; 30(8): 742-63. [http://dx.doi.org/10.1080/01421590802217199] [PMID: 18946818]

[65] Prince KJ, Van De Wiel M, Scherpbier AJ, Can Der Vleuten CP, Boshuizen HP. A qualitative analysis of the transition from theory to practice in undergraduate training in a PBL-medical school. Adv Health Sci Educ Theory Pract 2000; 5(2): 105-16. [http://dx.doi.org/10.1023/A:1009873003677] [PMID: 12386467]

[66] McLachlan JC, Bligh J, Bradley P, Searle J. Teaching anatomy without cadavers. Med Educ 2004; 38(4): $418-24$. [http://dx.doi.org/10.1046/j.1365-2923.2004.01795.x] [PMID: 15025643]

[67] Rizzolo LJ, Stewart WB. Should we continue teaching anatomy by dissection when ...? Anat Rec B New Anat 2006; 289(6): 215-8. [http://dx.doi.org/10.1002/ar.b.20117] [PMID: 17109419]

[68] Bergman EM, Prince KJ, Drukker J, van der Vleuten CP, Scherpbier AJ. How much anatomy is enough? Anat Sci Educ 2008; 1(4): 184-8. [http://dx.doi.org/10.1002/ase.35] [PMID: 19177406]

[69] Drake RL. A unique, innovative, and clinically oriented approach to anatomy education. Acad Med 2007; 82(5): 475-8. [http://dx.doi.org/10.1097/ACM.0b013e31803eab41] [PMID: 17457071]

[70] Papa V, Vaccarezza M. Teaching Anatomy in the XXI Century: New Aspects and Pitfalls. Scientific World J 2013. https:/www.hindawi.com/journals/tswj/2013/310348/

[71] Johnson EO, Charchanti AV, Troupis TG. Modernization of an anatomy class: From conceptualization to implementation. A case for integrated multimodal-multidisciplinary teaching. Anat Sci Educ 2012; 5(6): 354-66. [http://dx.doi.org/10.1002/ase.1296] [PMID: 22730175]

[72] Gogalniceanu P, Palman J, Madani H, et al. Traditional undergraduate anatomy educationa contemporary taboo? ANZ J Surg 2010; 80(1-2): 6-7. [http://dx.doi.org/10.1111/j.1445-2197.2009.05167.x] [PMID: 20575870] 
[73] Collins JP. Are the changes in anatomy teaching compromising patient care? Clin Teach 2009; 6(1): $18-21$. [http://dx.doi.org/10.1111/j.1743-498X.2008.00256.x]

[74] Older J. Anatomy: a must for teaching the next generation. Surgeon 2004; 2(2): 79-90. [http://dx.doi.org/10.1016/S1479-666X(04)80050-7] [PMID: 15568432]

[75] Winkelmann A. Anatomical dissection as a teaching method in medical school: a review of the evidence. Med Educ 2007; 41(1): 15-22. [http://dx.doi.org/10.1111/j.1365-2929.2006.02625.x] [PMID: 17209888]

[76] Heylings DJ. Anatomy 19992000: the curriculum, who teaches it and how? Med Educ 2002; 36(8): $702-10$. [http://dx.doi.org/10.1046/j.1365-2923.2002.01272.x] [PMID: 12191052]

[77] Dyball R, Members of the Education Committee of the Anatomical Society and others . Setting a benchmark for anatomical knowledge and its assessment (A core curriculum for the teaching of anatomy to medical students) 2003. Available at: http://www.anatsoc.org.uk/ linkfiles/anat-core-curric.htm

[78] Waterston SW, Stewart IJ. Survey of clinicians attitudes to the anatomical teaching and knowledge of medical students. Clin Anat 2005; 18(5): 380-4.

[http://dx.doi.org/10.1002/ca.20101] [PMID: 15971223]

(C) Jordan et al.; Licensee Bentham Open

This is an open access article licensed under the terms of the Creative Commons Attribution-Non-Commercial 4.0 International Public License (CC BY-NC 4.0) (https://creativecommons.org/licenses/by-nc/4.0/legalcode), which permits unrestricted, non-commercial use, distribution and reproduction in any medium, provided the work is properly cited. 